\title{
Analysis on Influence of the Western Piano Schools on Piano Education in China
}

\author{
Xiaolong Deng ${ }^{1}$, Jing Wang $^{1}$ \\ ${ }^{1}$ XingTai University, Xingtai, 054001, China
}

Keywords: Western countries; Piano schools; Piano education

\begin{abstract}
Western countries have formed their unique piano schools in piano manufacturing, performance and education, which exert an important influence on nationalization and internationalization of piano art. This paper specifically analyzes the influence of western piano schools on the piano education in China based on brief introduction to generation of western piano schools and the features of different schools, and properly rethinks the current piano education in China, with the hope of promoting the further development of piano education in China.
\end{abstract}

\section{Introduction}

The piano learning was started from the first piano researched and made by an Italian in the $18^{\text {th }}$ century. As time goes by, the piano manufacturing and performance skills were gradually improved and perfected, and finally, piano became the musicians' favorite keyboard instrument in modern society. Compared with the western countries, the piano development period in our country is relatively short and our piano education develops slowly, so there is a large gap between our piano education level and the world's advanced level. Piano, which was formally introduced in our country in the time of the Opium Wars, was gradually popularized and developed correspondingly after the reform and opening-up in the $20^{\text {th }}$ century. During the development process, the western piano schools exert a huge influence on the piano education in our country, promoting the modernization development and improvement of the piano education in our country to some extent.

\section{Generation and major features of western piano schools}

\section{Generation of western piano schools}

Since the appearance of the first piano in Europe in the $18^{\text {th }}$ century, the famous German instrument builder Gottried Silbermann, his "twelve apostles" and other persons had made hard efforts to continuously improve the piano performance skills and finally got the piano art out of the predicament, and then, piano was popularized, promoted and further developed in European society; in 1770, it formally replaced the traditional clavichord and became one of the most important keyboard instruments in the European classical period ${ }^{[1]}$. Meanwhile, as piano derived from clavichord and a lot of piano-related teaching works and musical performance works appeared in Europe in the $18^{\text {th }}$ century, such as The Art of Keyboard Touching written by Couperin, The Rules of Musical Performance by Jean-Philippe Rameau and other teaching works as well as Bach Inventions et Sinfonias, Scarlatti's Sonatas, The Well-Tempered Clavier, Haydn Sonata, British and French suites and many other performance works, a set of piano education systems formed for the piano art including theoretical music creation, ways of performance, and different musical styles, and western piano schools of different styles formed due to the influence by different styles during development.

\section{Major western piano schools and their features}

\section{Russian piano school}

The current Russian piano school was established in the $19^{\text {th }}$ century, and the famous piano artist Tchaikovsky was a representative who created many classic works of piano art. On the basis of these traditional and classic works of piano art and with the ideological quintessence of piano art in western European countries, the Russian piano school with distinctive characteristics was gradually formed 
under the active promotion by several artists. Firstly, the Russian piano school attached importance to signing during piano performance. During the initial development of Russian piano school, instruments in the musical performance were strictly limited due to the influence by the background of strict social church systems, thus most musical performances were carried out under the human signing. Meanwhile, under the influence of the famous artist Tchaikovsky's performance ideology, the performance form with strong ethnic characteristics formed in the Russian piano school, could express artists' thoughts and emotions during the performance, and exerted an important influence on this piano school's characteristic of paying attention to signing. Secondly, this school focused on pursuit for musical essence. In the advancement and development of Russian piano school, importance was attached to obtaining powerful musical features through the performance form with granular sensation, thus the apparent color effect and strong expansionary force in the piano performance had become attractive points of piano playing in the Russian piano school.

French piano school

France is one of the important places where the piano art and culture originated; in the development process, a lot of artists and piano playing masters appeared; under the influence of the French nation's romanticism, the French piano playing characteristics of being clear, elegant but accurate finally formed ${ }^{[2]}$. Firstly, the French piano school paid more attention to the specific ideological connotation of piano performance. The French piano school had a tradition of digging deeply into the connotation of the works before performing it, laid emphasis on cultivating the performance feelings, and encouraged performers to gradually form unique performance styles on this basis. Secondly, this school focused on the sense of balance in musical performance. The French piano school always paid attention to controlling the performance strength and to pursuing the sense of balance during performance, so as to bring the audience with special audio-visual enjoyment.

German and Austrian piano school

Many outstanding pianists appeared in the historical development process of piano art in Germany and Austria, and typical representatives included Beethoven, Liszt and Schumann. The piano perfmormance of German and Austrian piano school also had its distinctive characteristics: Firstly, the performance style was rigorous and exquisite; the performance practice is strictly faithful to the works; the thoughts and emotions of the works were expressed through an objective manifestation form. Secondly, extremely strong creativity: The German and Austrian piano school attached importance to careful analysis on ideological connotation of the works while paying high attention to faithfulness to the works, could accurately grasp the internal relation between different performance elements in the analysis, and then expressed the thoughts and emotions of the works in an objective and rational way.

\section{Influence of major western piano schools on piano education in China}

With the efforts of several generations of piano theory research experts, performers and educators in the over three hundred years of piano art development history in western countries, a set of theoretically and practically complete education thought and system have formed, and such education thought and system have gradually penetrated into the piano education in different countries with the wide spread of piano culture in the world and have exerted a far-reaching influence on piano education in different countries, including China. Since the early 1920s when our country formally set up the conservatory for the first time, there have been two or three hundred professional conservatories throughout the nation by now, and the huge multi-level musical art education system has been established. Especially, there are millions of musical art lovers involved in piano learning, and the vigorous development of various piano competitions have facilitated the great progress of our piano education in recent years. However, throughout the development history of piano education in China, the influence of western piano schools on piano education development in our country can be seen everywhere from content and teaching system of piano education to creation of piano music. 


\section{Influence of western piano schools' educational thoughts on piano education in China}

The piano education development in our country inherited the authority principle of western piano schools, and the characteristics of western piano education are imitated everywhere in the teaching process; therefore, the corresponding national innovation is absent, and some impassable performance rules are gradually established in students' thinking consciousness during the education, which have limited the students from giving play to their subjective initiative and from cultivating their creativity. As mentioned by the famous music research scholar Liao Naixiong, a false teaching thought always exists in the piano education in our country, namely teachers teach students with the method how the teachers themselves learned the piano playing ${ }^{[3]}$. The existence of such false ideological understanding has resulted in students' excessive imitation, which not only leads to teachers' self-centered teaching thought, but also strictly limits students within teachers' teaching control and causes the absence of ideological originality.

\section{Influence of western piano schools' playing skills on piano education in China}

The Vienna finger playing school represented by the famous piano playing master Mozart also plays a great promoting role in the development of playing skills in our piano education, while the virtuoso performance thought created by the Stuttgart high-finger playing school has exerted a far-reaching influence on piano education in both Europe and China. The performance teaching in the early-stage piano education in China was affected mainly by the thoughts of the two schools; thus, the piano education during development in our country paid more attention to training of piano playing skills, and the teaching thought of focusing firstly on skills and then on musical expression has gradually formed imperceptibly; encouraging students to learn to play large piano performance works in the teaching process to show the piano performer's performing skills and the conservatory's teaching achievements is unfavorable to the long-term healthy development of piano education in our country. In the current stage, many western piano performance experts who came to our country to give corresponding performances or lectures unanimously thought that piano learners in our country have exquisite finger playing techniques but lack the ability in music expression. The famous Chinese piano educator Chen Bigang also emphasized during his research that, compared with advanced countries, tones in piano performance in China are lean and dry and the scale of overall performance effect is not grand enough. Even some experts directly point out that Chinese people play the piano with fingers after receiving the piano education, while foreigners give a piano performance with their whole bodies after receiving the piano education.

\section{Influence of western piano education system on the piano education in China}

The western schools' piano education, which is mainly based on school education and social education, integrates the piano education into the details of social life by relying on the developed economic foundation and profound traditional cultural deposits of the advanced western cultural country so that piano education becomes a national artistic education with a relatively high popularizing rate and is highly valued by the society, school and families. Although our country' $s$ piano education system also inherits the educational thoughts and features of western piano schools' educational system, the popularizing rate of piano education in our country is relatively low, and it almost become an education for the "noble" stratum. The students in the vast rural areas and underdeveloped areas in our country even haven' $t$ seen pianos, let alone receiving the basic piano music education ${ }^{[4]}$. At present, since no educational thought system which conforms to the fundamental realities of our country has been constructed in the world' s school music education system, the teaching materials adopted in the piano education in our country are generally the western education versions, which have been popular for years. besides, in the social education system, the most important factor to influence the quality of piano education is the teacher' $\mathrm{s}$ comprehensive quality. The good and bad social piano teachers are intermingled and even some of them didn' $t$ receive the professional and systematic training for piano education, so they teaching capability is rather poor, which restricting the improvement of piano education level in our country. 


\section{Rethinking on piano education in China}

\section{The western piano schools' influence on the piano education in China is excessively far-reaching.}

As a music art culture generated in the western society, the piano art education has the development characteristics of western culture and profound European national culture accumulation, influenced by the local politics, economy, culture, education and other environments and highlights the western cultural features and national cultural styles, so it shows its powerful vitality and normative nature during the art spreading process. Therefore, although being developed for a hundred years, as influenced by the culture of western piano schools, Chinese piano education still has its full-bodied western cultural ambience but relatively poor effect of localization, without constructing the characteristics of the Chinese nation.

The western piano art plays a huge role in promoting the development of piano education in

\section{China.}

Any culture will certainly be affected, assimilated and permeated by the foreign lands' traditional culture during its worldwide transmission so the piano art is also not an exception. It is also inevitably influenced by the assimilation of our culture during transmission in our country but the western piano art still exerts huge influences upon development of piano education in China. Up to this day, under the influence of our national culture, a certain number of national culture and art works were produced, reflecting the permeation of the eastern culture to the western culture and the integration of eastern and western cultures. However, such permeation and integration fail to basically wipe away the influence of the western piano art on the piano education in our country so our modern piano creation still inherits and develops many features of the western schools, which plays a role in promoting the development of piano art.

\section{The road of national innovation and development of piano art in China}

Although the piano education in our country is influenced by the western piano schools and inherits the western piano art' $\mathrm{s}$ development style and ideological characteristics, it doesn' $t$ completely copy the western piano art during the process of gradual development and improvement but gradually walks to the road of national innovation while paying close attention to the national ideology and culture ${ }^{[5]}$. The improvement and development of science and technology, which have a huge influence upon the modern cultural and artistic fields and educational means, promote the emancipation of thinking mode. With compliance with the trend of the times, the piano education in our country gradually constructed the educational pattern which conforms to the fundamental realities of our country.

\section{Endeavor to build a system of piano education with Chinese characteristics}

In order to make breakthrough progress for the piano education of our country in contemporary society and to gradually get rid of bondage of educational thoughts of the western piano schools, firstly, it is required to carefully learn to study the performance mode with our national and cultural characteristics and corresponding system of educational theory with great concentration, strengthen the building of teaching materials of school education and establish the teaching material system with rich national and cultural characteristics while earnestly learning the successful construction experience of the western piano schools so as to realize the changes from low-level etudes to high-level music and from traditional music to modern music in piano education and to form the serialized educational thought system. Furthermore, it is also required to be based on the traditional national music of our country and actively absorb the modern musicians' piano composition skills so as to create the piano works with both our national cultural ambience and spirit of the times and to promote the innovative development of the piano education in our country through integration of Chinese and western. 


\section{Conclusion}

To sum up, since the western piano education developed relatively early, it has obtained very glorious artistic achievements at present. Comparatively, our school and social piano educations have a long way to go; only when our piano education insists on our national characteristics in its development and integration of eastern and western cultures, can it finally form its characteristic piano art schools to push the international development of piano education in our country.

\section{References}

[1] Tian Ge. Analysis on Artistic Characteristics and Teaching Commonality of Principal Western Piano Schools. Popular Literature, 2012(16):283-284.

[2] Cheng Zeng. Comparative Study on Teaching of French Piano Schools and the Piano Education in China. Journal of Fujian Socialist College, 2014(2):113-114.

[3] Yang Mei. Enlightenment of Western Piano Science to the Development of Chinese Piano Education Business. Yellow River of the Song, 2014(12):80.

[4] Ren Yanrong. Study on Western Piano Education in the 20th century. Family of the Drama, 2013(12):69-69.

[5] Li Jing. Primary Exploration on Development Influence and Educational System of Russia Piano Schools. Popular Literature, 2011(20):245. 